\title{
A Pregnant Women's Group: an Innovative Approach to Reduce Maternal and Neonatal Deaths in Developing Countries
}

\author{
Bhagawan Das Shrestha \\ $\mathrm{PhD}$ scholar, Mewar University \\ Email: bdshrestha3@gmail.com
}

\begin{abstract}
In Nepal, the utilization of maternal, newborn and child health (MNCH) care services exhibit big gaps between rich and poor, for instance poorest quintile is at $10.7 \%$ skill births attendant services while richest at $81.5 \%$, despite the services being free of cost. Pregnant women's group $(P W G)$ approach was initiated to address $M N C H$ inequities prevailing in the disadvantaged community. The PWG is a socially cohesive peer support group of 8-15 pregnant women and postnatal mothers who meet monthly for participatory teaching and learning sessions on MNCH cares and semi-annual publicly group commitment meeting. At the meetings, husbands, mothersin-law and father-in-law verbally commit to support their pregnant wives and daughters-in-law in present of pregnant women. Local health staff also commits to provide those services. The literature review was done on women's group and its impact of $\mathrm{MNCH}$. The findings were compared with PWG approach of Nepal in line with "the World Health Organization's recommendation on community mobilization through facilitated participatory learning and action cycles with women's groups for maternal and newborn health". The PWG approach fulfill the WHO's consideration of more than $30 \%$ of pregnant women participation, the role of men and other members of the community, visual methods and ethnic group mix. The PWG approach can be a strategy to reduce the high burdens of maternal and newborn morbidity and mortality in developing countries. The approach needs monthly participatory teaching learning sessions, use of a behavioural mapping mat for self-monitoring and biannually publicly group commitments by husbands and mother and father-in-laws.
\end{abstract}

\section{KEY WORDS}

Disadvantaged, inequality, behaviour mapping, pregnant women's group approach, commitment, Nepal, WHO.

\section{INTRODUCTION}

\section{Background of the PWG initiation and history}

Nepal, officially the Federal Democratic Republic of Nepal, is a federal republic and landlocked country of over 26.4 million people in South Asia. Nepal's gross domestic product (GDP) for 2012 was estimated at over $\$ 17.921$ billion (adjusted to nominal GDP). The Gross Domestic Product per capita in Nepal was last recorded at 426.48 US dollars in 2014. Nepal has low human development index (HDI) ranking to 145 and scored 0.548 in 2914. 
In Nepal, there are 75 districts which are divided into Village Development Committees (VDCs). The VDC is divided into nine wards. The ward is the lowest development unit in Nepal. Government of Nepal, Ministry of Health and Population has provision that in each ward there is usually one Female Community Health Volunteer (FCHV) who facilitates the Mother's Group meeting in each month. In the Mother's Group meeting, the pregnant women and mothers of newborns are having limited participation and maternal and newborn health care messages are not being delivered to intended target i.e. pregnant women and postnatal mothers. A strategy to rejuvenate mother's groups - the creation of pregnant women's groups was started in 2003 in Bara district of Nepal by targeting sub-group for interventions (Plan Nepal 2003).

A pregnant women's group (PWG) is a socially cohesive peer support group of 8-15 pregnant women and postnatal mothers who live in the same ward and meet monthly. The integrated PWG approach helps pregnant women self-monitor their utilization of maternal and newborn health services, while positive peer pressure within the group acts as motivation for behavior change. The groups not only empower women to advocate to husbands and in-laws on the necessity of visiting health service providers but also put pressure on local health providers (health assistants, staff nurses, auxiliary nurse midwives, and auxiliary health workers from government health facilities) to ensure quality and timely health services are provided.

The pregnant women and postnatal mothers self-monitor the utilization of antenatal and postnatal services along with birth preparedness plan and newborn birth registration. They monitor the utilization of services by using a social behavioural mapping mat in which they paste different colored marks "Tika".

\section{Monthly health education sessions of pregnant women's groups:}

This meeting is facilitated by FCHVs and technical backstopping is provided by local health facility staff. These sessions include health education around pregnancy and birth, together with self-monitoring by pregnant women on their behaviour mapping of utilization of health services. The health education messages include use of antenatal care (ANC) services; birth preparedness plans (including money, blood, transport, use of skill birth attendants - SBAs); danger signs during pregnancy, at birth and after delivery, and for newborns; and newborn care. Jeewan Suraksha (Life Saving) Action Cards were developed by the government and are already used in all 75 districts of Nepal. The card is an A4 size pictorial card that is green on one side and red on the other. The green side has illustrations of optimal antenatal care, birth preparedness plans, post-natal care, and neonatal care; the red side has illustrations of danger signs during the pregnancy, at birth, after delivery, and for neonates. Each pregnant woman in the PWG is given a card to be hung on a wall at home as a reminder and brought to monthly meetings. 


\section{Behavioral mapping with information on health indicators}

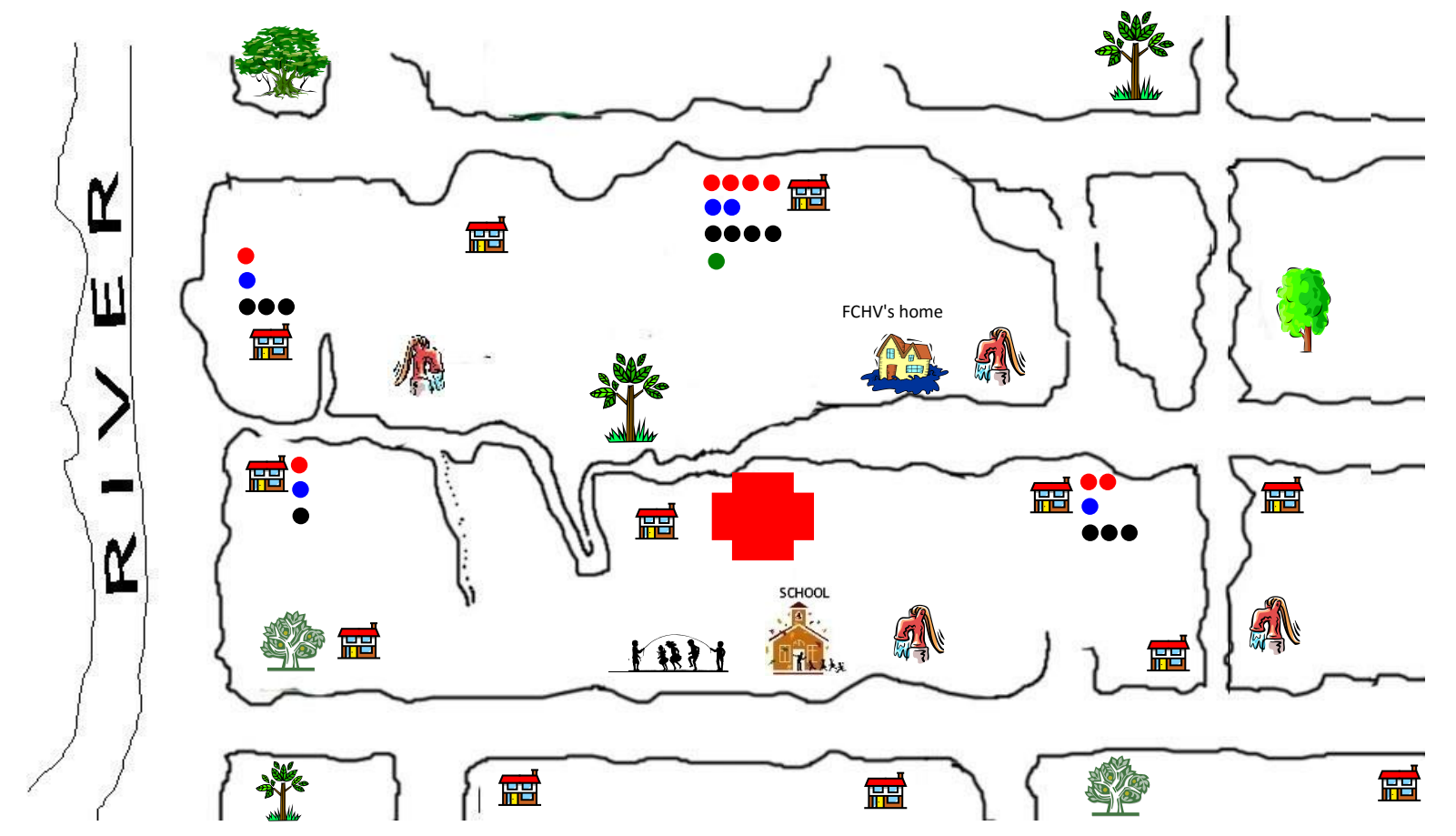

The five essential principles of newborn care are evidence based and include: 1) drying and stimulating the newborn with a soft, dry cloth immediately after birth;2) putting the newborn on the mother's chest and initiating skin-to-skin contact; and encouraging early initiation of breast feeding within the first hour; 3) providing advice on early initiation of breastfeeding and exclusive breastfeeding for up to six months; 4) not applying anything on the cord stump after navel care with chlorhexidine 4\%; and 5) delaying bathing of the newborn until after the first 24 hours. Pregnant women are given iron and folic acid for prevention of anemia, and misoprostol for management of postpartum hemorrhage, during meetings and chlorhexidine $4 \%$ to apply on newborns' umbilicus is distributed to women at seven months of gestation, all supplied by the government.

\section{Behavioural mapping mat:}

Women monitor their own needs for and utilization of health services using a behavioral mapping mat [See below sample] with stickers (Tika) and pictorial representations, a technique that does not require literacy. The mat contains a map of the village, showing the location of houses where pregnant women in the group live. Women place a different colored Tika (tiny adhesive stickers) next to their house for each pro-health activity they achieve, including ANC visits, iron tablet intake, postnatal care, tetanus vaccinations, birth preparedness plans, and 
money, transport, SBA contact number, three people for blood transfusion in case of postpartum hemorrhage, postnatal vitamin A, and birth registration of newborn along a time-line of their own pregnancy. These mats are inexpensive; with start-up costs of USD \$3 per group and operational costs less than USD \$1 per group per year for Tikas, glue sticks, and photocopying in 2014. Mapping creates healthy competition among pregnant women for positive behavior change and utilization of maternal and child health care services.

\section{Legend of behavioural mapping mat}

(1) Red Tika: Antenatal care checkup,

(2) Black Tika: Iron and folic acid

(3) Sky Blue Tika: Tetanus toxoid,

(4) Yellow Tika: Preparation for delivery (money, transport and blood) and procurement of clean home delivery kit

(5) Brinjal Tika: Albendazole at fourth month of pregnancy

(6) Green Tika: Post-Partum (PP) Vitamin A and

(7) Light green Tika: birth registration

\begin{tabular}{|c|c|c|c|c|c|c|c|}
\hline \# & $\begin{array}{c}\text { Tika } \\
\text { Colour }\end{array}$ & Symbol & Indicator & \# & $\begin{array}{c}\text { Tika } \\
\text { Colour }\end{array}$ & Symbol & Indicator \\
\hline 1 & $\begin{array}{l}\text { (RED - } \\
\text { (4 times) }\end{array}$ & & $\begin{array}{c}\text { Antenatal } \\
\text { Check UP } \\
+ \\
\text { Post Natal } \\
\text { Check Up }\end{array}$ & 5 & (BRINJ) & & $\begin{array}{l}\text { Albendazo } \\
\text { le at } 4^{\text {th }} \\
\text { month of } \\
\text { pregnancy }\end{array}$ \\
\hline 2 & $\begin{array}{l}\text { (BLACK } \\
-(6 \\
\text { months) }\end{array}$ & & $\begin{array}{l}\text { Iron and } \\
\text { Folic Acid }\end{array}$ & 6 & $\begin{array}{l}\text { (GREEN } \\
- \text { ) }\end{array}$ & & $\begin{array}{c}\text { Vitamin A } \\
\text { within } 6 \\
\text { weeks of } \\
\text { delivery }\end{array}$ \\
\hline & months) & & & & & & \\
\hline
\end{tabular}




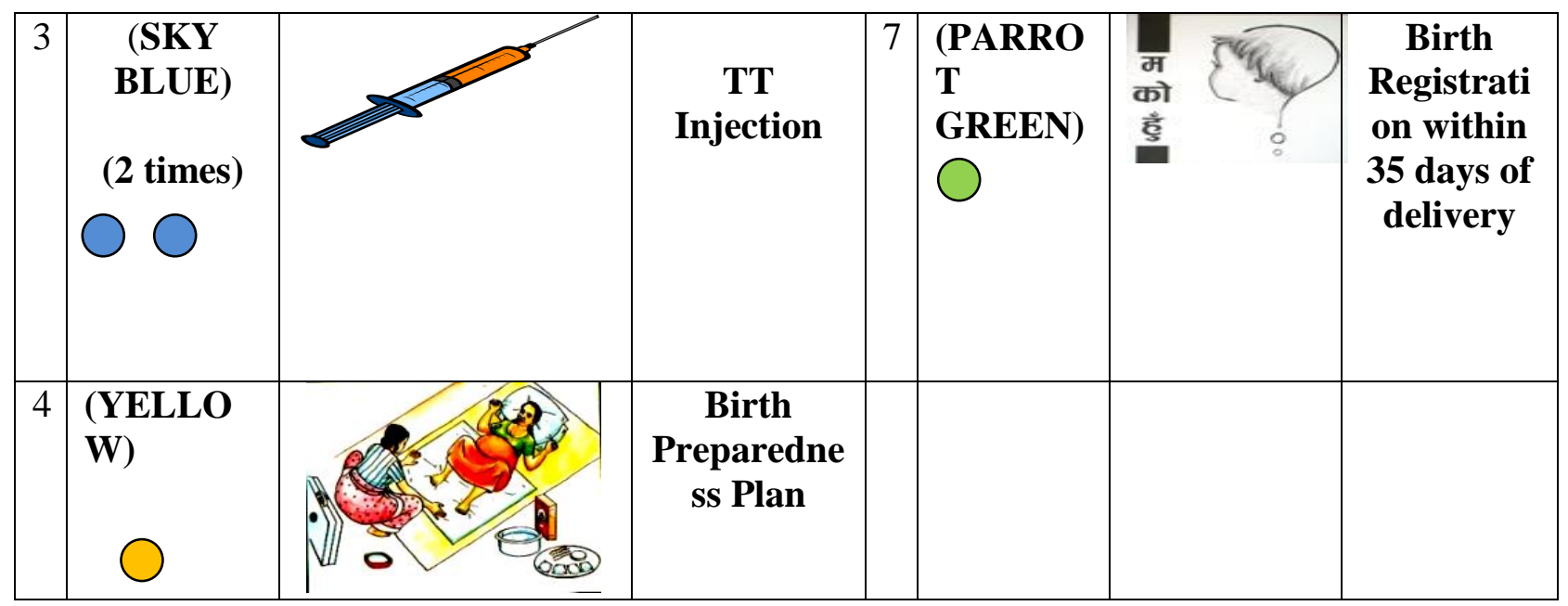

The pregnant women's husbands and their mother in laws are also encouraged to participate. Female community health volunteers (FCHVs) facilitate the meetings. Outreach workers from the local health facility are encouraged to participate and support the sessions technically. In some areas, group meetings are linked with outreach clinics operated by the outreach workers. After completion of the PWG meeting, the FCHV distributes iron, folic acid, deworming tablets for pregnant mothers and condom and pills for postnatal mothers.

In the PWG process, group facilitators provide essential health information to pregnant women, as well as husbands and in-laws, related to pregnancy and birth. Information often includes how to make birth preparedness plans, how to recognize danger signs in pregnancy and in newborns, when and why to seek health care, how to properly care for newborns, and the importance of antenatal care, proper nutrition, iron and folic acid and deworming tablets, and tetanus vaccination.

\section{Publicly group commitments meeting}

Pregnant women group approach also includes the organization of semi-annual VDC (village development committee) level public commitment meetings. Every six months community meetings will be organized, attended by FCHVs, pregnant women and new mothers, their inlaws and husbands, and local health facility staff. At the meetings, husbands and mothers-in-law verbally commit to support their pregnant wives and daughters-in-law in front of the PWG members, FCHVs, and local health staff. These meetings take place twice a year in a VDC.

All attendees are encouraged to publicly commit to carry out recommended activities that lead to healthier outcomes for mothers and infants. For example, all the pregnant women commit to a minimum of four ANC check-ups, consume iron and folic acid tablets from the 4th month of pregnancy until six weeks after child delivery, two doses of tetanus vaccine, deworming tablet at 4th month of pregnancy, delivery at hospital or birthing center or by SBA, and the importance of 
hand-washing before touching newborns. Decision makers (mothers-in-law and husbands), health service providers, and FCHVs also commit to support pregnant women and mothers. For example, husbands and mothers-in-law commit to ensure that their wives and daughters-in-law have transportation to the nearest health facilities for ANC check-ups, and health workers commit to welcoming all women at centers and providing high quality services, as outlined in the government's maternal and newborn health program guidelines. Please see below flex chart in local language Nepali which is used for the public group commitments. 
गर्भवती महिलाको अभिभावकले लिनै पर्ने सपथहरु:

9. म मेरो गर्भवती श्रीमती/बुहारीलाई $\gamma$ पटक गर्भवती जाँच गराउछु।

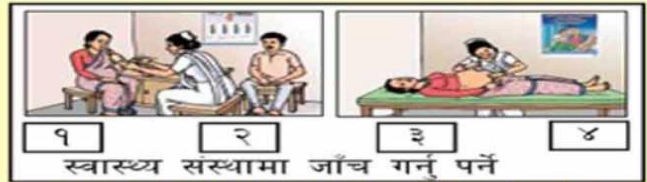

२. म मेरो गर्भवती श्रीमती/बुहारीलाई चौथो महिनामा जुकाको औषधी खुवाउंछु ।

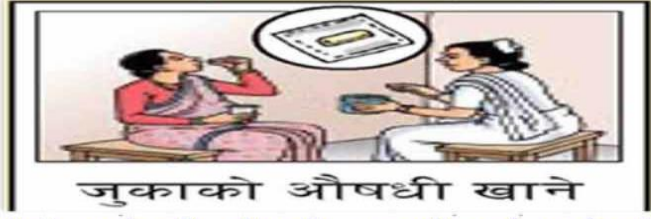

३. म मेरो गर्भवती श्रीमती/बुहारीलाई गर्भवती भएकोचौथो महिना देखि सुत्केरी भएको ६

हप्तासम्म आइरन चक्की खुवाउंछु । महिना

\begin{tabular}{|c|c|c|c|c|c|}
\hline चौथ & पाँचौ & छ़,ठौ & सातौ & आठौं & नखों \\
\hline 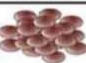 & -393 & $\frac{393}{33}$ & 자의 & 자의 & -13 \\
\hline
\end{tabular}

गर्भावस्थामा आईरन चक्की खाने

૪. म मेरो गर्भवती श्रीमती/बुहारीलाई गर्भअवस्थामा $\gamma$ महिना पछि पुरा मात्रामा टि.टि. खोप लगाउन लगाउंछु।

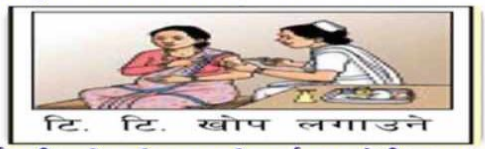

५. म मेरो गर्भवती श्रीमती/बुहारीलाई सुत्केरी अवस्थाको लागि पैसा, दक्ष प्रसुतिकर्मी, यातायात, सुत्केरी सामाग्री र रगत दिने ३ जना व्यक्तीको अनिवार्य व्यवस्था गर्दछु।
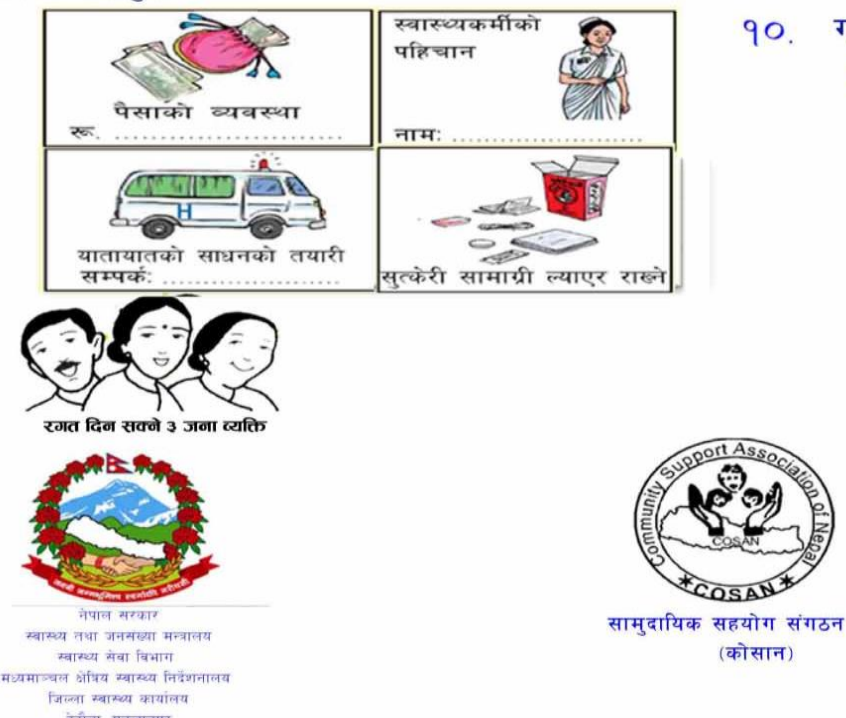

सामुदायिक सहयोग संगठन नेपाल (कोसान)
म मेरो गर्भवती श्रीमती/बुहारीलाई स्वास्थ्य संस्थामा नै बच्चा जन्माउन लगाउंछु ।
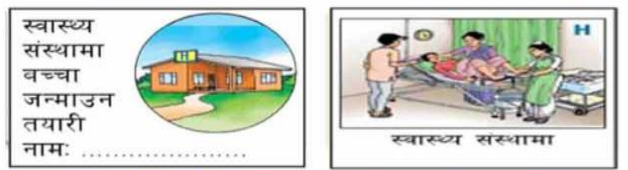

म मेरो गर्भवती श्रीमती/बुहारीलाई गर्भाअवस्था तथा सुत्केरी अवस्थामा अन्य समय भन्दा बढि पटक पोषिलो खानेकुरा खुवाउनेछु ।

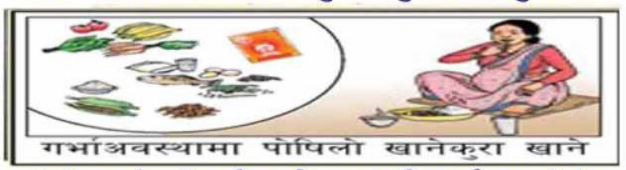

म मेरो गर्भवती श्रीमती/बुहारीलाई सुत्केरी अवस्थामा सुत्केरी र बच्चाको ३ पल्ट (२४ घण्टा भित्र, तेश्रो दिन र सातौं दिन) स्वास्थ्यसंस्थामा जाँच गराउन लैजान्छु ।

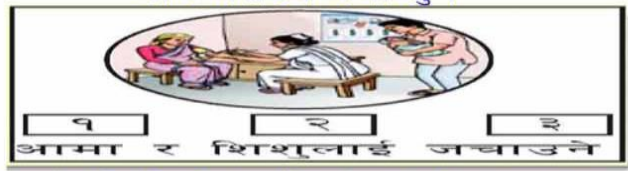

९. म मेरो गर्भवती श्रीमती/बुहारीलाई गर्भवती अवस्थामा दिउँसोको समयमा पनि २ घण्टा आराम गर्ने अवसर दिनेछु

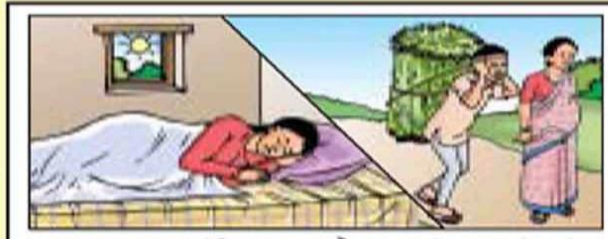

आराम गर्ने र गह्रौ भारी नबोक्ने

१०. गर्भवती आमालाई गह्नौ भारी बोक्न तथा बढि शारीरिक परिश्रम हुने कार्य गर्न दिने छैन। 
ISSN: 2362-1303 (Paper) | elSSN: 2362-1311(Online)

JOURNAL OF ADVANCED ACADEMIC RESEARCH (JAAR)

July 2016

\section{Logical framework pregnant women's group}

The conceptual framework outlined below shows that how the pregnant women's groups approach increases the utilization of maternal newborn and child health care services.

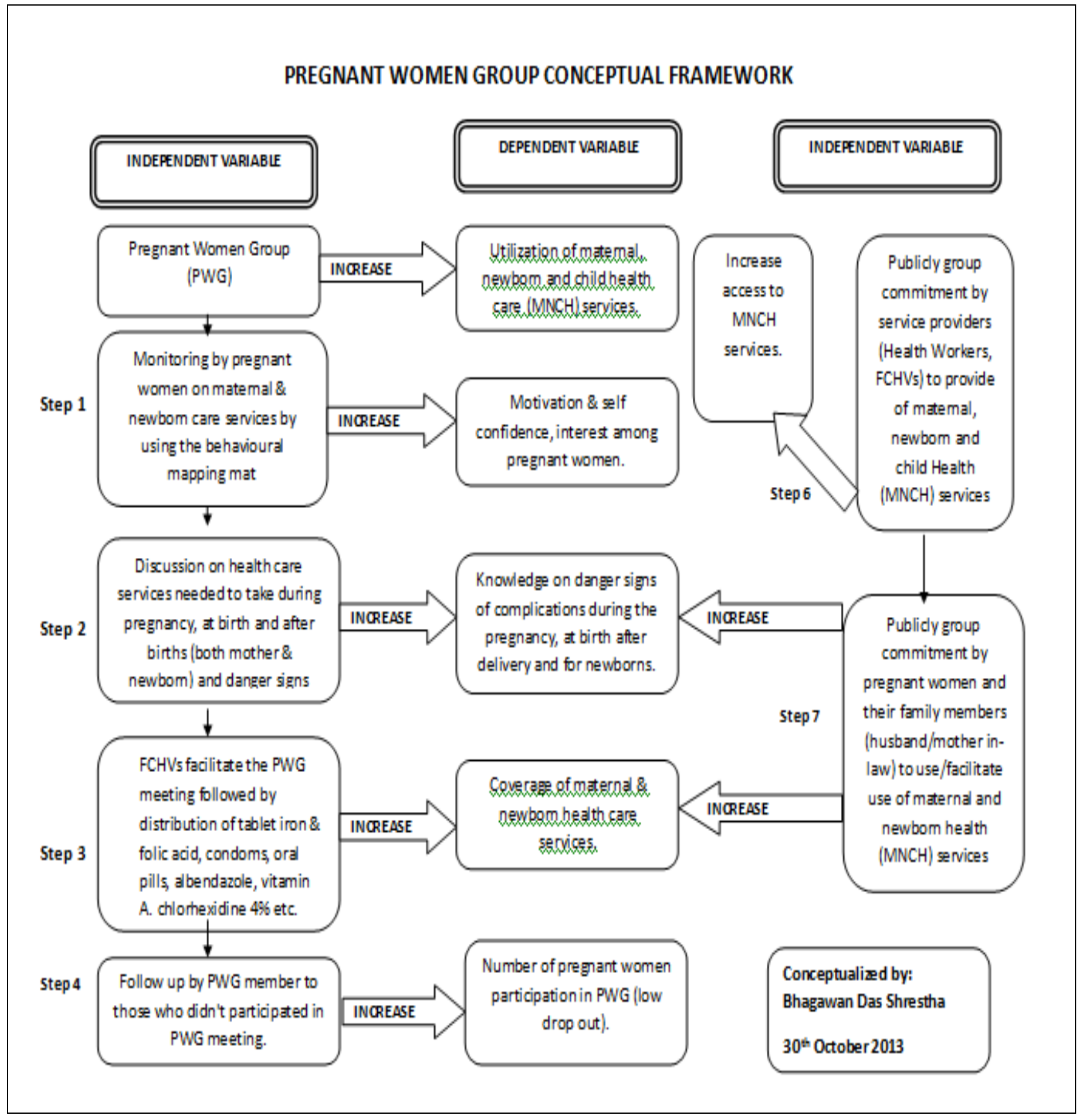




\section{Studies including WHO recommendation}

As per "WHO recommendation on community mobilization through facilitated participatory learning and action cycles with women's groups for maternal and newborn health", WHO 2014 has recommended as follows:

\begin{tabular}{|c|c|c|}
\hline Recommendation & $\begin{array}{l}\text { Quality of } \\
\text { Evidence }\end{array}$ & $\begin{array}{l}\text { Strength of } \\
\text { Recommendation }\end{array}$ \\
\hline $\begin{array}{l}\text { Implementation of community mobilization through } \\
\text { facilitated participatory learning and action cycles } \\
\text { with women's groups is recommended to improve } \\
\text { maternal and newborn health, particularly in rural } \\
\text { settings with low access to health services. } \\
\text { Implementation of facilitated participatory learning } \\
\text { and action cycles with women's groups should focus } \\
\text { on creating a space for discussion where women are } \\
\text { able to identify priority problems and advocate for } \\
\text { local solutions for maternal and newborn health. }\end{array}$ & $\begin{array}{l}\text { MODERATE for } \\
\text { newborn mortality; } \\
\text { LOW for maternal } \\
\text { mortality; } \\
\text { LOW for } \\
\text { care-seeking } \\
\text { outcomes }\end{array}$ & \\
\hline \multicolumn{3}{|c|}{$\begin{array}{l}\text { Remarks: } \\
\text { Evidence about the positive effect of the intervention on newborn mortality was clearer than the } \\
\text { evidence of its effect on maternal health and on care-seeking outcomes. More research is needed } \\
\text { to improve our understanding of the effects on these other outcomes, and the effects in differen } \\
\text { contexts. } \\
\text { The Guideline Development Group (GDG) recommended that this intervention be implemented } \\
\text { with close monitoring and evaluation to ensure high quality implementation, and with prior } \\
\text { adaptation to the local context. Any intervention designed to increase access to health services } \\
\text { should be implemented in tandem with strategies to improve health services. Where the quality } \\
\text { of services is poor, women may understandably choose not to use them despite mobilization } \\
\text { efforts. } \\
\text { The recommendation should be considered in conjunction with the implementation } \\
\text { considerations indicated below. }\end{array}$} \\
\hline
\end{tabular}

\section{Considerations to be taken into account for implementation}

- To have an impact, the time period of the intervention should be no shorter than three years.

- There needs to be adequate coverage of the intervention in terms of density of groups in the population. There is some evidence that the intervention might be more successful where more than 30\% of pregnant women participate, however the evidence at present is not definitive. The effect may also vary by context, e.g., may depend on prior existence, strength and cohesion of local social networks. 
- High quality facilitators are key in establishing and maintaining groups and helping them to be effective; good training and support of facilitators is therefore essential.

- Although it is a 'community intervention', like any intervention at large scale, it must be supported by appropriate structures, systems and processes. For example, each facilitator should be responsible for no more than $8-10$ groups per month to act effectively and resources must be in place to support this.

- Implementation should include awareness of the potential harms (gender violence, conflict with health providers or other community members, etc.). Potential harms should be monitored throughout implementation so that they can be managed.

\section{The political/social context}

- Political support (national and local level) is essential.

- The intervention must be adapted to reflect each country's context, specific capacities and constraints.

- Implementing the intervention as part of national community health developmental strategies/plans or other community development structures is likely to enhance coverage and sustainability.

- The women's groups should not operate in isolation. To be effective they need the cooperation of the other social groups, e.g. recognizing the value of maternal and newborn health, providing responsive and accountable health services. Co-operation from non-health sectors may be crucial for implementing group plans e.g. road maintenance.

\section{Specific local factors that might be relevant to implementation}

- History of participation in the communities, existence of other groups, local decision making structures and processes should be taken into account in design/implementation.

- Data are needed on local barriers and facilitators of implementation and acceptability of the intervention to women.

- Implementation should consider the role of men and other members of the community (e.g. religious groups, mothers-in-law) and how and when they participate in the process.

- The design of the process used with groups should be adapted according to the groups in question, e.g. accounting for levels of literacy/numeracy, preferences for oral versus visual methods, etc.

- Ethnic group mix, religion, caste and other social categories affecting group dynamics need to be considered in developing the approach (e.g. how and where groups are formed).

\section{Research Gaps Women's Group}

It would be useful to have more information about:

- this intervention in urban areas 
- this intervention in conjunction with stronger quality improvement measures for health services and the impact on care-seeking behaviour

- Participatory learning and action cycles with other population groups (i.e., men, grandmothers, etc.)

- additional non-health benefits

- potential harms of these types of interventions

- strategies to address potential tension with men in those contexts where there is sensitivity to women's gatherings or potential harms

- barriers and facilitators for implementation

- acceptability of the intervention to women

- whether or not the intervention causes an increased value to be placed on women by women themselves and by the broader society

- processes and quality (e.g. facilitation) of implementation

- whether or not a certain proportion of pregnant women need to participate in the groups in order for them to have an impact on maternal and newborn health

- sustainability, how long external inputs are required and processes for scaling-up

It was suggested that qualitative data, e.g. from process evaluations, could be synthesized. The synthesis might help answer some of the outstanding questions about this intervention.

\section{Study Comparison}

The comparison of the four Women's Group interventions is shown in Table \#1.

Table\# 1: Comparison of the four Women's Group interventions

\begin{tabular}{|l|l|l|l|l|}
\hline Interventions & $\begin{array}{l}\text { 1. The MIRA } \\
\text { Makwanpur } \\
\text { Study Nepal } \\
\mathbf{( 1 9 9 9 - \mathbf { 2 0 0 9 } )}\end{array}$ & $\begin{array}{l}\text { 2. Women's } \\
\text { Groups of } \\
\text { Bangladesh, } \\
\text { India, Malawi, } \\
\text { and Nepal. }\end{array}$ & $\begin{array}{l}\text { 3. The Effect of } \\
\text { Scaling up } \\
\text { Women's Groups } \\
\text { on Birth } \\
\text { Outcomes in } \\
\text { Bangladesh Study }\end{array}$ & $\begin{array}{l}\text { 4. The Bara } \\
\text { Pregnant } \\
\text { Women Group } \\
\text { (PWG) Impact } \\
\text { Study in Nepal }\end{array}$ \\
\hline References & $\begin{array}{l}\text { Manandhar D S } \\
\text { et al. 2004 }\end{array}$ & Prost A et al.2013 & Azad K et al. 2010 & $\begin{array}{l}\text { Maskey M K et } \\
\text { al. 2011 }\end{array}$ \\
\hline $\begin{array}{l}\text { Research } \\
\text { design }\end{array}$ & $\begin{array}{l}\text { Cluster } \\
\text { Randomized } \\
\text { Controlled } \\
\text { Trial (RCT) }\end{array}$ & $\begin{array}{l}\text { A systematic } \\
\text { review and meta- } \\
\text { analysis of RCTs }\end{array}$ & RCT & $\begin{array}{l}\text { Cross sectional- } \\
\text { comparative } \\
\text { study and the } \\
\text { data were } \\
\text { collected by } \\
\text { applying }\end{array}$ \\
\hline
\end{tabular}




\begin{tabular}{|c|c|c|c|c|}
\hline & & & & $\begin{array}{l}\text { "Motherhood } \\
\text { Method", - a } \\
\text { variant of } \\
\text { Participatory } \\
\text { community } \\
\text { Survey (Maskey } \\
\text { and DesChene, } \\
\text { 2005). }\end{array}$ \\
\hline Target group & $\begin{array}{l}\text { Women's } \\
\text { groups }\end{array}$ & Women's groups & Women's groups & $\begin{array}{l}\text { Pregnant } \\
\text { Women Group }\end{array}$ \\
\hline $\begin{array}{l}\text { Health } \\
\text { education } \\
\text { methods }\end{array}$ & $\begin{array}{l}\text { Participatory } \\
\text { learning rather } \\
\text { than instruction }\end{array}$ & $\begin{array}{l}\text { Participatory } \\
\text { learning and action }\end{array}$ & $\begin{array}{l}\text { Participatory action } \\
\text { and learning for } \\
\text { women }\end{array}$ & $\begin{array}{l}\text { Participatory } \\
\text { action and } \\
\text { learning } \\
\text { including } \\
\text { pregnant women } \\
\text { self- monitoring } \\
\text { of utilization } \\
\text { MNH services }\end{array}$ \\
\hline $\begin{array}{l}\text { Impact on } \\
\text { maternal and } \\
\text { neonatal } \\
\text { deaths }\end{array}$ & $\begin{array}{l}\text { Intervention } \\
\text { group was } \\
\text { nearly } 30 \% \\
\text { lower than in } \\
\text { the control } \\
\text { group. } \\
\text { Hierarchical } \\
\text { modeling- } \\
\text { taking } \\
\text { clustering into } \\
\text { account- } \\
\text { yielded an odds } \\
\text { ratio of } 0 \cdot 70 \\
\text { (95\% CI } \\
0 \cdot 53 \text { - } 0 \cdot 94 \text { ) } \\
\text { for neonatal } \\
\text { mortality in the } \\
\text { intervention } \\
\text { clusters } \\
\text { compared with } \\
\text { the control } \\
\text { clusters. }\end{array}$ & $\begin{array}{l}\text { A } 37 \% \text { reduction in } \\
\text { maternal mortality } \\
\text { (odds ratio } 0 \cdot 63 \text {, } \\
95 \% \text { CI } 0 \cdot 32- \\
0 \cdot 94 \text { ) and a } 23 \% \\
\text { reduction in } \\
\text { neonatal mortality } \\
(0 \cdot 77,0 \cdot 65-0 \cdot 90 \text { ). } \\
\text { A subgroup } \\
\text { analysis of the four } \\
\text { studies in which at } \\
\text { least } 30 \% \text { of } \\
\text { pregnant women } \\
\text { participated in } \\
\text { groups showed a } \\
55 \% \text { reduction in } \\
\text { maternal mortality } \\
(0 \cdot 45,0 \cdot 17-0 \cdot 73 \text { ) } \\
\text { and a } 33 \% \\
\text { reduction in } \\
\text { neonatal mortality } \\
(0 \cdot 67,0 \cdot 59-0 \cdot 74 \text { ). }\end{array}$ & $\begin{array}{l}\text { Cluster-level mean } \\
\text { NMR (adjusted for } \\
\text { stratification and } \\
\text { clustering) was } \\
33 \cdot 9 \text { deaths per } \\
1000 \text { live births in } \\
\text { the intervention } \\
\text { clusters compared } \\
\text { with } 36 \cdot 5 \text { per } 1000 \\
\text { in the control } \\
\text { clusters (risk ratio } \\
0 \cdot 93,95 \% \text { CI } \\
0 \cdot 80-1 \cdot 09 \text { ). }\end{array}$ & $\begin{array}{l}\text { The study has } \\
\text { demonstrated } \\
\text { with high } \\
\text { precision that } \\
\text { PWG members } \\
\text { have reduced } \\
\text { risk (about 50\% } \\
\text { less) of dying } \\
\text { during } \\
\text { pregnancy, } \\
\text { childbirth and } \\
\text { puerperium as } \\
\text { compared to the } \\
\text { non-PWG } \\
\text { members. Their } \\
\text { children also } \\
\text { have similar } \\
\text { lower risk of } \\
\text { dying during } \\
\text { perinatal and } \\
\text { infancy periods. }\end{array}$ \\
\hline
\end{tabular}




\begin{tabular}{|c|c|c|c|c|}
\hline $\begin{array}{l}\text { Drawbacks or } \\
\text { advantages }\end{array}$ & $\begin{array}{l}\text { Only } 37 \% \text { of } \\
\text { pregnant } \\
\text { women } \\
\text { participated in } \\
\text { the Women } \\
\text { Groups. }\end{array}$ & $\begin{array}{l}\text { The pregnant } \\
\text { women participated } \\
\text { in the Women } \\
\text { Groups studies are } \\
\text { not more than 51\% } \\
\text { as shown below: } \\
36 \% \text { (Fottrell et al } \\
2013 \text { ) and 3\% } \\
\text { (Azad et al 2010) } \\
\text { in Bangladesh, 2\% } \\
\text { (More et al 2012) } \\
\text { and 37\% (Tripathy } \\
\text { et al 2010) in India, } \\
\text { 10\% (Colbourn et } \\
\text { al 2013) and 51\% } \\
\text { (Lewycka et a; } \\
\text { 2013) in Malawi } \\
\text { and 37\% in Nepal. }\end{array}$ & $\begin{array}{l}\text { Only } 3 \% \text { of } \\
\text { pregnant women } \\
\text { participated in the } \\
\text { Women Groups. }\end{array}$ & $\begin{array}{l}90 \% \text { pregnant } \\
\text { women and } 10 \% \\
\text { postnatal } \\
\text { mothers }\end{array}$ \\
\hline Interpretation & $\begin{array}{l}\text { Women groups } \\
\text { with } \\
\text { participatory } \\
\text { teaching } \\
\text { learning } \\
\text { processes help } \\
\text { to reduce } \\
\text { neonatal rate in } \\
\text { Makwanpur } \\
\text { Nepal }\end{array}$ & $\begin{array}{l}\text { With the } \\
\text { participation of at } \\
\text { least a third of } \\
\text { pregnant women } \\
\text { and adequate } \\
\text { population } \\
\text { coverage, women's } \\
\text { groups practicing } \\
\text { participatory } \\
\text { learning and action } \\
\text { are a cost-effective } \\
\text { strategy to improve } \\
\text { maternal and } \\
\text { neonatal survival in } \\
\text { low-resource } \\
\text { settings. }\end{array}$ & $\begin{array}{l}\text { For participatory } \\
\text { women's groups to } \\
\text { have a significant } \\
\text { effect on neonatal } \\
\text { mortality in rural } \\
\text { Bangladesh, } \\
\text { detailed attention to } \\
\text { programme design } \\
\text { and contextual } \\
\text { factors, enhanced } \\
\text { population } \\
\text { coverage, and } \\
\text { increased } \\
\text { enrolment of newly } \\
\text { pregnant women } \\
\text { might be needed. }\end{array}$ & $\begin{array}{l}\text { The pregnant } \\
\text { women group - } \\
\text { participatory } \\
\text { teaching learning } \\
\text { with self- } \\
\text { monitoring } \\
\text { increase use of } \\
\text { MNH care } \\
\text { services and to } \\
\text { reduce the } \\
\text { maternal and } \\
\text { newborn deaths } \\
\text { in developing } \\
\text { countries like } \\
\text { Nepal. }\end{array}$ \\
\hline Conclusion & \multicolumn{4}{|c|}{$\begin{array}{l}\text { The participatory teaching learning and action methods with pregnant women } \\
\text { self-monitoring of behavioural mapping of maternal and newborn health } \\
\text { (MNH) services is an effective intervention to change behaviour of the women } \\
\text { to increase uptake of maternal, newborn and child health services and reduce } \\
\text { maternal and newborn deaths in low resource setting developing countries like } \\
\text { Nepal. }\end{array}$} \\
\hline
\end{tabular}




\section{DISCUSSION}

Prost A. et al.2013 (Lancet 2013; 381: 1736-46) showed a 55\% reduction in maternal mortality $(0.45,0.17-0.73)$ and a $33 \%$ reduction in neonatal mortality $(0.67,0.59-0.74)$, a subgroup analysis of the four studies (India, Bangladesh, Nepal and Malawi) in which at least 30\% of pregnant women participated in groups. The intervention was cost effective by WHO standards and could save an estimated 283000 newborn infants and 41100 mothers per year if implemented in rural areas of 74 Countdown countries.

Maskey M K et al. 2011 mentioned that the pregnant women group (PWG) study demonstrated with high precision that PWG members have reduced risk (about 50\% less) of dying during pregnancy, childbirth and puerperium as compared to the non-PWG members. Their children also have similar lower risk of dying during perinatal and infancy periods.

The finding of the 50\% reduction of maternal mortality in PWG study in Nepal is almost same reduction $(55 \%)$ in maternal mortality in the four countries meta-analysis where pregnant women are at least $30 \%$ in the women group. But in case of neonatal mortality reduction, there is $50 \%$ in the PWG study and $33 \%$ in the four countries meta-analysis.

The WHO's (2014) recommendation on community mobilization through facilitated participatory learning and action cycles with women's groups for maternal and newborn health has mentioned that the considerations to be taken into account for implementation of women's group is as follow: There is some evidence that the intervention might be more successful where more than $30 \%$ of pregnant women participate, however the evidence at present is not definitive. Thus this consideration is fulfilled by pregnant women's group approach where there are more than $90 \%$ pregnant women in the group.

The WHO's (2014) recommendation has also mentioned the specific local factors that might be relevant to implementation of the women's group are as follows:

1. Implementation should consider the role of men and other members of the community (e.g. religious groups, mothers-in-law) and how and when they participate in the process.

2. The design of the process used with groups should be adapted according to the groups in question, e.g. accounting for levels of literacy/numeracy, preferences for oral versus visual methods, etc.

3. Ethnic group mix, religion, caste and other social categories affecting group dynamics need to be considered in developing the approach (e.g. how and where groups are formed).

The pregnant women group (PWG) approach fulfills above three WHO's specific local factors that might be relevant to implementation of the women's group. In the PWG approach, the pregnant women's husbands, mother-in-laws and father-in-laws are participated in a bi-annually publicly group commitments session. In the session, they commit to facilitate the pregnant 
women to get antenatal care, institutional delivery and postnatal care including newborn care. The PWG approach uses a visual method - a pictorial behavioural mapping mat for selfmonitoring by pregnant women in the monthly health education session. The mat can be used easily by an illiterate. The PWG has ethnic mixed group as PWG study showed in total $81.8 \%$ respondents were from the so called disadvantage caste and remaining $18.2 \%$ from the so called upper caste.

\section{CONCLUSIONS}

The pregnant women group approach fulfills considerations and local factors of WHO's recommendation on women's group. It should be replicated in the disadvantaged community where maternal, newborn and child health $(\mathrm{MNCH})$ care services coverage is low. The following points are recommended

- Repeated monthly participatory teaching learning on key maternal, newborn and child health $(\mathrm{MNCH})$ care services messages (like danger signs during the pregnancy, at birth and after birth, and danger signs for newborn) directly to a Pregnant Women's Group (PWG);

- Pregnant women self-monitoring of the utilization of the MNCH care services by using a behavioural mapping mat during the monthly PWG meeting;

- Biannually publicly group commitments by husbands and mothers-in-law to support their pregnant wives and daughters-in-law for the utilization $\mathrm{MNCH}$ care services in front of the PWG members, FCHVs, and local health staff;

- The commitments by the local health facility staff to provide those $\mathrm{MNCH}$ services in the same biannually publicly group commitment meeting of husbands and mother in laws;

- Sharing the postnatal mothers' experiences and lesson learned in the pregnant women's group's meeting by postnatal mothers; and

- Scaling up the pregnant women's group approach in disadvantage community where the coverage of $\mathrm{MNCH}$ care services is low.

\section{References}

Audrey Prost, Tim Colbourn, Nadine Seward and et al (2013), Women's groups practising participatory learning and action to improve maternal and newborn health in lowresource settings: a systematic review and meta-analysis.Lancet 2013; 381: 1736-46

Azad K, Barnett S, Banrjee B, et al. (2010), Effect of scaling women's group on birth outcomes in three rural districts in Bangladesh: a cluster-randomised controlled trail. Lancet 2010; 375:1193-202

Baral, KP. (2006), Concept and approach of pregnant women's group: An approach to increase coverage of maternal health services in rural Nepal, Kathmandu: Nepal. 2006.

Colbourn T, Nambiar B, Bondo A, et al. Effects of quality improvement in health facilities and community mobilization through women's groups on maternal, neonatal and perinatal 
mortality in three districts of Malawi: MaiKhanda, a cluster randomised controlled effectiveness trial. Oxford Jounals, International Health 2013-08-29. Accessed on June 12, 2016 http://inthealth.oxfordjournals.org/content/early/2013/06/26/inthealth.iht011.full

Dipty Nawal, TV Sekhar, Srinivas Goli,(2013)' Decomposing the socioeconomic inequality in utilisation of maternal health-care services in selected Asian and sub-Saharan African countries. Lancet 2013; 381: special issue, S97.

Fottrell E, Azad K, Kuddus A, Younes L, Shaha S, Nahar T. (2013)The eff ect of increased coverage of participatory women's groups on neonatal mortality in Bangladesh: a clusterrandomised trial. JAMA Pediatric 2013 Sep; 167(9):816-25.

Lewycka S, Mwansambo C, Rosato M, et al.(2013), Eff ect of women's groups and volunteer peer counselling on rates of mortality,morbidity, and health behaviours in mothers and children in rural Malawi (MaiMwana): a factorial, cluster randomised controlled trial. Lancet 2013; 381: 1721-35. http://www.who.int/woman_child_accountability/ierg/reports/30a_Womens_groups_met aanalysis.pdf)

Manandhar DS, Osrin D, Shrestha BP, et al.(2004). members of the MIRA Makwanpur trial team. Effect of a participatory intervention with womens groups on birth outcomes in Nepal: cluster randomized controlled trial. Lancet 2004; 364: 970-79.

Maskey M.K, Baral K.P., Shah R, Shrestha BD, Janet L. \& Kenneth J. R. (2011). Field test results of the motherhood method to measure maternal mortality. Indian J Med Res 133, January 2011, pp 64-69

Maskey M.K, Baral K.P., Shrestha BD and et. al. (2008), Pregnant Women's Group Impact Study, Summary Report of Impact Assessment of Pregnant Women Group Strategy, Plan Nepal, Child Survival Project, Bara District, Nepal (2001-2006). Accessed on http://pdf.usaid.gov/pdf_docs/Pdaci677.pdf at page 41.

Ministry of Health and Poplulation (MOHP) [Nepal], New Era, and ICF International INC. (2012). Nepal Demographic Health Survey 2011. Kathamndu, Nepal:Ministry of Health and Population, New ERA, and ICF International, Calvarton, Maryland.

More NS, Bapat U, Das S, et al. Community mobilization in Mumbai slums to improve perinatal care and outcomes: a cluster randomized controlled trial. PLoS Med 2012; 9: e1001257.

Shrestha B.D. Pregnant Women's Groups and the Impact on Newborn's Mortalities in Bara District, Nepal. Nepal Public Health Association (NEPHA) Newsletter, Volume \#1 , Issue \# 2, Pg 8, November 2009

Tripathy P, Nair N, Barnett S, et al. Effect of participatory intervention with women's groups on birth outcomes and maternal depression in Jharkhand and Orissa, Inida: a clusterrandomised controlled trail. Lancet 2010; 375: 1182-92

WHO 2014, WHO recommendation on community mobilization through facilitated participatory learning and action cycles with women's groups for maternal and newborn health, Geneva. 